\title{
Flood hazard maps in Matucana village under climate change scenarios
}

\author{
JUAN W. CABRERA CABRERA \& LEONARDO F. CASTILLO NAVARRO \\ Facultad de Ingeniería Civil, Universidad Nacional de Ingeniería, Lima25, Peru \\ juancabrera@,uni.edu.pe
}

\begin{abstract}
Possible effects of climate change on floods magnitude and effects are discussed in this document based on existing data and projected changes in precipitation until 2099. This methodology is applied to Matucana Village, which suffers the effects of floods and debris flows. First, historical peak precipitation, fitted to Gumbel distribution, was used, After that, percentage projected changes of precipitation were used to obtain the new mean precipitation to each period 2010-2039, 2040-2069 and 2070-2099; these mean precipitations define a new Gumbel distribution for every time period. Then, projected maximal precipitations to 100 years of return period are estimated and the corresponding peak flow hydrographs were built. Finally, hazard maps are plotted. This application is possible because Matucana is located in a climatologically homogeneous basin. The final results suggest an important increase in magnitude and affected area by floods in the next 90 years under the A1FI emission scenario.
\end{abstract}

Key words AOGCM; climate change; flood; hazard map; IPCC scenarios; debris flow; Matucana, Peru

\section{INTRODUCTION}

Matucana village is located on the left bank of the Rimac River around $2375 \mathrm{~m}$ a.s.l. in the Western Chain of Central Peruvian Andes. In this zone there are two Rimac River tributary streams which impact on urban areas: Chucumayo and Paihua ravine. According to Cabrera and Castillo (2014) the possible effects of climate change are neglected in these ravines because they do not significantly add to their debris flow production. However, the secondary effect is more important: Paihua ravine could dam water of the Rimac River and produce floods on Matucana. This situation suggests the necessity of quantifying these possible effects and recognizes the possible hazard zones and reorganizing and preparing mitigation plans.

\section{STUDY METHODS}

Data

The Japan International Cooperation Agency (JICA 1988) carried out an assessment in Matucana Village and its results are used to analyse the effects of climate change. This assessment contains probabilistic analysis, including peak flows and isohyets maps on Rimac River basin.

Arithmetic mean values of the precipitation for the periods 2010-2039, 2040-2069 and 20702099 were estimated by using projected percentage changes according to the ECHAM4 (European Center - Hamburg 4), NCAR PCM (National Center for Atmospheric Research - Parallel Climate Model) and HADCM3 (Hadley Centre Coupled Model 3) models, which have the highest spatial resolution and the A1FI emission scenario (the last part of its name "FI" is by "fossil intensive"). This emission scenario was selected because it shows the most critical projections (Ruostenoja et al. 2003, IPCC 2007a).

Topography data are based on National Maps from the Instituto Geográfico Nacional (IGN). According with this data, main channel slope was estimated as 0.051 , concentration time as $4.47 \mathrm{~h}$ and lag time as 2.68 hours.

To estimate infiltration volume, analyses from CESEL (2004) and Castillo (2006) were used in which Rimac basin headwater shows characteristic like hydrologic soil type " $\mathrm{B}$ " and values between 79 to 83 could be assigned as curve number. To this research, 79 was assigned.

\section{Methodology}

The methodology of Cabrera and Castillo (2014) was applied that considers that the Rimac basin is located in a climatologically homogeneous region (Rau et al. 2011). 
Considering a percentage variation in monthly precipitation $\Delta P$

$$
P_{\text {proy.month } \cdot 1}=(1+\Delta P) \cdot P_{\text {month } \cdot 1}
$$

As cumulative monthly precipitation is the sum of every daily precipitation for that month, we can write:

$$
\sum_{1}^{30}\left(P_{\text {proy.daily.month } \cdot 1}\right)=(1+\Delta P) \cdot \sum_{1}^{30}\left(P_{\text {daily.month } \cdot 1}\right)
$$

Then, it's possible to estimate the projected maximal daily precipitation by applying the same variation $\Delta P$ :

$$
P_{\text {proy } \max . \text { daily } \cdot i}=(1+\Delta P) \cdot P_{\max . \text { daily } . i}
$$

and we can conclude that:

$$
P_{\text {proy } \max . i}=(1+\Delta P) \cdot P_{\max . i}
$$

Considering the maximal precipitation time series affected by $\Delta P$, we can get:

$$
\mu_{\text {proy }}=(1+\Delta P) \cdot \mu
$$

where: $\Delta P$ is projected changes of precipitation (\%) to the interval " $n$ "; $\mu$ is historical mean value of the maximal daily precipitation in the wettest month; $\mu_{\text {proy }}$ is projected mean value of the maximal daily precipitation in the wettest month. The interval " $n$ " could be: 2010-2039, 2040-2069 or 2070-2099.

This assumption does not affect the scattering (standard deviation) because the time series is affected homogeneously.

In this way, these two new parameters, mean value $\mu_{\text {proy }}$ and standard deviation $S$, define a Gumbel probability distribution function to every period of analysis and it is possible to estimate the new maximum precipitation for a return period $T r$ using the following expression:

$$
P_{\text {proy } \max }=\mu_{\text {proy }}+K * S
$$

where $K$ is the "frequency factor" and depends only on the time of return:

$$
K=-\sqrt{6} / \pi\{0.5772+\ln [\ln (\operatorname{Tr} /(\operatorname{Tr}-1))]\}
$$

This maximum precipitation is used to build the peak flows hydrograph by the application of the SCS unit hydrograph method and HEC-HMS software. SCS storm meteorological model and type 1 storm were considered together with characteristics of the region.

Finally, these results and topography were input to FLO2D software to simulate the scenario. The output will show affected areas, maximum depth and water and solid volumes.

\section{RESULTS AND DISCUSSION}

\section{Precipitation probabilistic distribution}

Analysis of peak precipitation was realized by CESEL (2004). According with this, historical maximal precipitation data in Rimac basin have a standard deviation $s=15.26$ and arithmetic mean value $\mu=17.14$.

Projections from ECHAM4, NCAR PCM and HADCM3 were applied to generate three scenarios: maximal (by using ECHAM4) mean (mean projections to these three models) and minimal (by using HADCM3). These scenarios are represented by new Gumbel distributions whose parameters are summarized in Table 1 . This table includes the maximum precipitation to 100 years of return period. 
Table 1 Mean values and maximum precipitation to $\operatorname{Tr}=100$ years to different scenarios and different time periods.

\begin{tabular}{lllllllll}
\hline & \multicolumn{2}{l}{ Historical } & \multicolumn{2}{l}{$2010-2039$} & \multicolumn{2}{c}{$2040-2069$} & \multicolumn{2}{c}{$2070-2099$} \\
& $\mu$ & $\mathrm{P}_{100}$ & $\mu$ & $\mathrm{P}_{100}$ & $\mu$ & $\mathrm{P}_{100}$ & $\begin{array}{l}\mu \\
(\mathrm{mm})\end{array}$ & $\begin{array}{l}\mathrm{P}_{100} \\
(\mathrm{~mm})\end{array}$ \\
\hline Maximum projected change & 17.14 & 65.02 & 17.49 & 65.37 & 17.59 & 65.47 & 18.65 & 66.53 \\
Mean projected change & - & - & 17.13 & 65.01 & 17.20 & 65.08 & 17.21 & 65.09 \\
Minimal projected change & - & - & 16.90 & 64.78 & 16.03 & 63.91 & 14.69 & 62.57 \\
\hline
\end{tabular}

Table 2 Peak flows for historical data and maximal scenarios. $\mathrm{Tr}=100$ years.

\begin{tabular}{lllll}
\hline & \multicolumn{2}{l}{ Peak flow $\left(\mathrm{m}^{3} / \mathrm{s}\right)$} & & \\
& Historical & $2010-2039$ & $2040-2069$ & $2070-2099$ \\
\hline Maximum projected change & 503.5 & 509.7 & 511.5 & 530.5 \\
\hline
\end{tabular}

The minimal scenarios show a reduction in precipitation of between $-0.37 \%(2010-2039)$ and $3.77 \%$ (2070-2099) and do not represent a crescent hazard to the village. The mean scenarios show too many small variations, between $-0.01 \%(2010-2039)$ and $0.11 \%(2070-2099)$, and they do not justify additional analysis. The maximal scenarios show increments of $0.54 \%, 0.69 \%$ and $2.32 \%$ to the periods 2010-2039, 2040-2069 and 2070-2099, respectively; these amounts do not appear to be important, but they were analysed because they represent the most critical scenario.

The estimated peak flows corresponding to the maximal scenarios are summarised in Table 2. The effects of projected variations in precipitation on discharges produce increments of up to 27 $\mathrm{m}^{3} / \mathrm{s}$ on the $2070-2099$ period, which represents $5.37 \%$ (see Fig. 1). This excess of flow could increase the areas affected by flood and will be simulated with FLO2D.

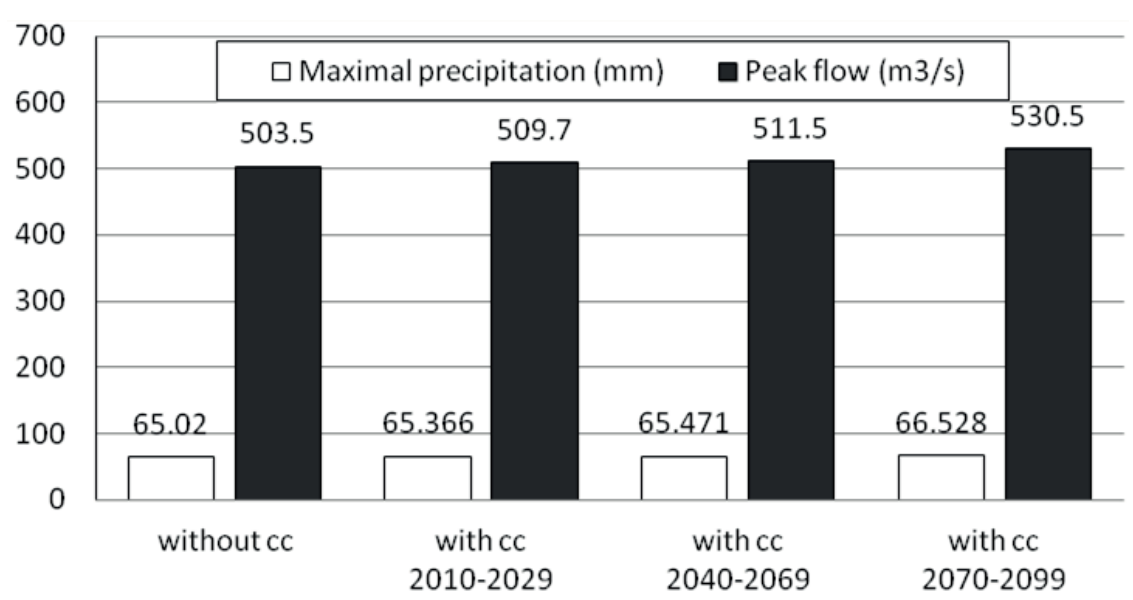

Fig. 1 Peak flows and maximum precipitation to different scenarios. Emission scenario A1FI.

\section{Flood simulation}

FLO2D was used for simulations with a grid size of $20 \times 20 \mathrm{~m}$. These include the occurrence of debris flow in the Paihua ravine, which dams the Rimac River. Sediment concentration was assumed distributed from $22 \%$ to $35 \%$ in Paihua (Castillo 2006) with clean water in Rimac. The results are summarised in Table 3.

According to the results, maximal inundated areas could increase up to $19.71 \%$ with respect to the estimated peak flow without climate change, affecting the economy of the population in Matucana. This percentage represents $28000 \mathrm{~m}^{2}$, including urban and rural areas.

Figure 2 shows that approx. four blocks would be affected by floods in the historical analysis; however, this amount increases to approx. 11 blocks under the maximum scenario 2040-2069, which represents an increment of $175 \%$ of the affected area. Affected buildings include the church, the high school, medical centre, police department and more than 40 family houses. 
Table 3 Comparison between expected debris flow to historical data analysis and projected data analysis.

\begin{tabular}{llll}
\hline & $\begin{array}{l}\text { Maximum precipitation } \\
(\mathrm{mm})\end{array}$ & $\begin{array}{l}\text { Peak flow } \\
\left(\mathrm{m}^{3} / \mathrm{s}\right)\end{array}$ & $\begin{array}{l}\text { Maximum inundated área } \\
\left(\mathrm{m}^{2}\right)\end{array}$ \\
\hline $\begin{array}{l}\text { Historical data } \\
\text { Maximum scenario }\end{array}$ & 65.02 & 503.5 & 142000 \\
2010-2039 & 65.37 & 509.7 & 164800 \\
$\begin{array}{l}\text { Maximum scenario } \\
\text { 2040-2069 }\end{array}$ & 65.47 & 511.5 & 170000 \\
$\begin{array}{l}\text { Maximum scenario } \\
\text { 2070-2099 }\end{array}$ & 66.53 & 530.5 & 167200 \\
\hline
\end{tabular}

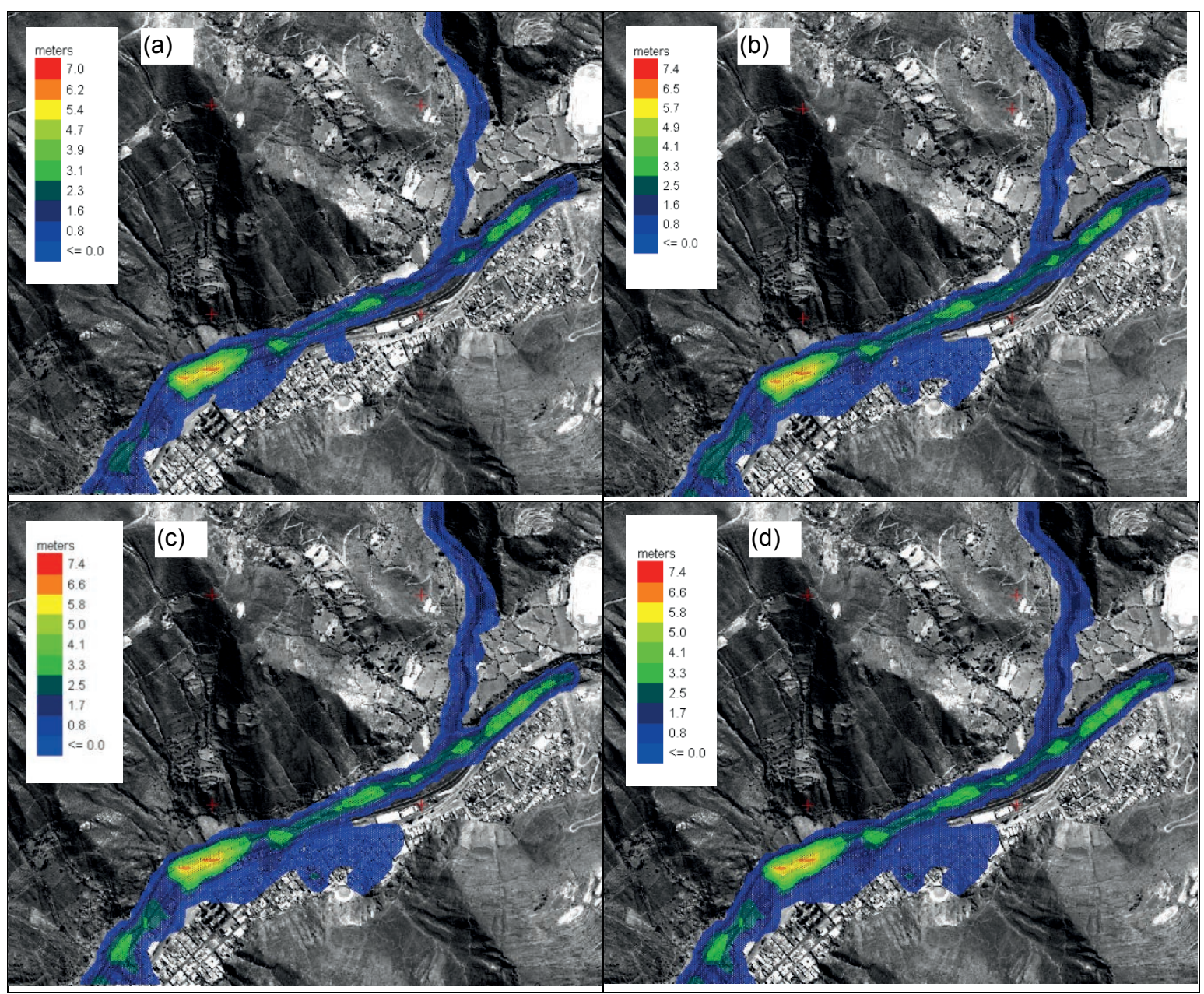

Fig. 2 Maximum inundated areas and maximum depth of water in Matucana village. (a) Scenario without climate change. (b) Maximum scenario 2010-2039. (c) Maximum scenario 2040-2069. (d) Maximum scenario 2070-2099. Emission scenario A1FI. Region 11.

Also, maximum depths of water increase up to $0.4 \mathrm{~m}$ over the expected depth, which is an increment of $5.7 \%$, up to depths of $1.7 \mathrm{~m}$ in the city. These changes have a more important affect on the urban population and increase the possibility of loss of human life.

Another effect is the increase of flow velocities, which reach up to $16.1 \mathrm{~m} / \mathrm{s}, 15.82 \%$ more than the expected the peak flow velocities without climate change. The increment in this dynamic could produce an increment in structural building failures and consequent economic and human life losses. 


\section{CONCLUSIONS}

Climate change could produce increases of $2.32 \%$ in maximal precipitation to 100 years of return period. This corresponds to an increment of $5.37 \%$ in peak flows to the same return period.

These changes could produce an increment of up to $19.71 \%$ in areas affected by flood, to a return period of 100 years, considering a future world of very rapid economic growth, low population growth, rapid introduction of new and more efficient technology and intensive use of fossil oil (A1FI emission scenario). This amount represents an increment of approx. 175\% in affected urban areas. According to simulations, the depth of flood could reach $0.8 \mathrm{~m}$ in the village, which would halt every economic activity and affect important buildings like the medical centre. $A$ posteriori simulation should consider possible structural measures to control this effect.

\section{REFERENCES}

Cabrera, J. and Castillo, L. (2014) Climate Change and Debris Flow: hazards maps in Matucana Village under IPCC scenarios. Hydrology in a Changing World: Environmental and Human Dimensions. Proceedings of FRIEND-Water 2014, France, October 2014. IAHS Publ. 363. IAHS Press, Wallingford, UK (in press).

Castillo, L. (2006) Aplicación de un modelo numérico de flujo de escombros y lodo a una quebrada en el Perú. Civil Engineering Thesis. Universidad Nacional de Ingeniería. Lima, Perú.

CESEL Ingenieros S. A. (2004) Estudio hidrológico de la quebrada Collana. Lima, Perú.

IPCC (2007a) Climate Change 2007: The Physical Science Basis. Contribution of Working Group I to the Fourth Assessment Report of the Intergovernmental Panel on Climate Change, Cambridge University Press. New York, USA.

IPCC (2007b) Climate Change 2007: Synthesis Report. Contribution of working groups I, II and III to the Fourth Assessment Report of the Intergovernmental Panel on Climate Change, Cambridge University Press. New York, USA.

Japan International Cooperation Agency (1988) The Master Plan Study on the disaster prevention Project in the Rimac basin. Lima-Perú.

Rau, P. (2011) Correlation study between different phenomenon ENSO and precipitations indexes over the Peruvian Pacific coast. Institut National Polytechnique de Toulouse. Paul Sabatier University Toulouse III. M2 Report. France.

Ruosteenoja, K., et al. (2003) Future climate in world regions: an intercomparison of model-based projections for the new IPCC emissions scenarios. The Finnish Environment Institute. Helsinki, Finland. 